\title{
The Effect of Indirect Written Corrective Feedback to Arabic Language Intermediate Students' in Kuwait
}

\author{
Hamed A. Alhumidi (PhD) \\ College of Basic Education, PAAET, State of Kuwait \\ Sani Yantandu Uba \\ University of Leeds, UK
}

doi: 10.19044/esj.2016.v12n28p361 URL:http://dx.doi.org/10.19044/esj.2016.v12n28p361

\begin{abstract}
This study investigates the effect of indirect written corrective feedback to Arabic intermediate students in Kuwait. There are 20 participants altogether in this study, ten male and ten female. They each wrote two assignments on the same topic. No feedback was received on the first assignment, and the second was conducted after indirect feedback was offered to them on the first task. The results show that indirect feedback is effective in improving their writing and language skills. The results also indicated a higher number of spelling errors than any other errors. The findings of this study suggest some teaching implications which include raising students' awareness of the need to avoid many writing errors. Teachers should not correct all students' errors, but should only correct those errors which are deemed necessary to correct. Teachers should also focus their attention on teaching and learning tasks, which concentrate on indirect written feedback rather than direct feedback. Again, as the leaners seem to have more problems with spelling errors rather than any other errors, teachers should devise strategies which concentrate on improving such errors, and writing correct words. This study advocates a large scale of studies which cover the wider context of Kuwaiti intermediate students.
\end{abstract}

Keywords: Written corrective feedback, direct feedback, indirect feedback, metalingual corrective feedback, intermediate students

\section{Introduction}

A number of studies have been conducted on written corrective feedback, as well as several arguments on its efficacy (Ferris, 2011, Ellis, 2009, Sheen et al., 2009, Van Beuningen et al., 2012, Van Beuningen, 2010, Truscott, 2007, Ferris, 2006, Ferris and Roberts, 2001, Truscott, 1996, Hyland and Hyland, 2006). The focus of the students' research on written 
corrective feedback varies, with some focus on form (Bruton, 2009, Lee, 2011, Kao, 2013, Long, 1996). Others focus on the oral feedback on specific linguistic features (Lyster, 2004, Han, 2002), as well as focussing on the feedback writing collaboration (Wigglesworth and Storch, 2012), whereas some studies offer explicit written corrective feedback (Yilmaz, 2012, Santos et al., 2010, Bitchener and Knoch, 2009). Some research is concerned only with indirect feedback, while others study both direct and indirect feedback (Mirzaii and Aliabadi, 2013, Erel and Bulut, 2007, Hashemnezhad and Mohammadnejad, 2012, Beuningen et al., 2008, Baker and Bricker, 2010). However, a significant number of studies on students' written corrective feedback have been conducted, particularly on second language learners, particularly the English language. There is a lack of a substantial amount of research on native speakers' of Arabic written corrective feedback, particularly in Kuwaiti intermediate schools. In this study, we investigate the written corrective feedback of native Arabic speakers in Kuwaiti intermediate schools. This research seeks to address the following questions:

1. What kinds of errors are recur in Arabic intermediate students' essay writing?

2. What kind of feedback do Kuwaiti Arabic intermediate students require in their essay writings?

It is pertinent to review relevant literature regarding the concept of feedback and studies on written corrective feedback.

\section{Literature Review Written corrective feedback}

As noted above, there are several arguments for the efficacy of offering written corrective feedback, with some researchers being of the opinion that offering written corrective feedback does not improve or assist learners' language accuracy (Kepner, 1991, Sheppard, 1992, Truscott, 1996, Doughty and Long, 2008). Truscott (1996) is among the proponents who vehemently oppose written corrective feedback to students, and argues that written corrective feedback does not assist learners in the 'sense that students need much longer time to automate grammatical rules than could happen from one draft to another' (Montgomery and Baker, 2007). This group of proponents believe that learners should allow to themselves to be corrected since they are in a process of developing their language, and as such they would correct themselves automatically as time goes on. Truscott (1996) argues further that correcting some local errors is time consuming which prevents students from focussing more on aspects of writing - Students have a greater likelihood of improving over the course of one writing class (Montgomery and Baker, 2007). This suggests that giving feedback is timing consuming and that less attention is given to the actual process of writing, 
which would be more helpful to learners. However, the other group of proponents argue that learners could benefit from being offered feedback on local errors (Fathman and Whalley, 1990, Chandler, 2003, Ferris, 1997, Yilmaz, 2012, Van Beuningen et al., 2012, Hartshorn et al., 2010), on the premise that they have the ability to recognise some of the local errors and fix them (Montgomery and Baker, 2007). They stress that learners improve their language efficiency if they receive feedback on local errors. For example, Montgomery and Baker (2007) report that Ferris (1997) conducted a study on teacher feedback on 47 advanced English students as a second language leaner, as how students responded to teacher feedback. The results indicate that much of the feedback comments enabled the students to provide substantive revisions of their work.

Hyland and Hyland (2006) claim that 'second language learners are positive about teacher written feedback'. However, they argue that its contribution to writing development is still unclear on the immediate impact of revisions, or the longer term development of students' writing skills. They also report that some studies show that students may ignore or misuse teachers' feedback when revising their drafts. For example, Conrad and Goldstein (1999) and Ferris (1995) report that sometimes students misunderstand the written comments of their teachers. In some instances they understand the problems that their teachers highlight 'but are unable to come up with a suitable revision' (Hyland and Hyland, 2006). The debate is inconclusive on the effectiveness of written corrective feedback.

We will now turn my discussion to the various types of written feedback, of which there are several. This discussion will be limited to just three types - direct, indirect, and metalinguistic corrective feedback.

\section{Types of feedback}

Some of the debates on the effectiveness or ineffectiveness of written corrective feedback have been discussed above. We will now discuss some of the types of written feedback that teachers could offer to students. Ellis (2009) argues that there are various options available for teachers to offer feedback to their students. These options vary but he mainly considers the correction of linguistic errors. Some of these options include direct corrective feedback, indirect, metalinguistic, the focus of the feedback, electronic feedback, and reformulation. As mentioned above, we will limit our discussion to the first three options.

\section{a. Direct corrective feedback}

Direct feedback is concerned with providing the student with the correct form, for example, the teacher may delete an unnecessary word, phrase, or morpheme or they may 'insert a missing word, morpheme, and 
write the correct form above or near to the erroneous form’ (Ellis, 2009). For example:

A bus hit $\wedge$ man.

a

In this instance an article is missing as shown above. Ellis claims that one of the advantages of direct feedback is that it provides learners with explicit guidance about how to correct their errors. Ellis argues further that this type of feedback is essential if learners do not know what the correct form actually is. This same argument is raised by Ferris and Roberts (2001) on the premise that if learners have a low level of proficiency, this approach could assist them significantly. However, this approach has been criticised on the premise that learners may not engage in critical thinking since they have already been given the correct forms, as well as the fact that it inhibits the automatization of learners' language development. Although a study conducted by Sheen (2007) shows that 'direct corrective feedback can be effective in promoting the acquisition of specific grammatical errors' (Ellis, 2009).

\section{b. Indirect corrective feedback}

Ellis (2009) states that indirect corrective feedback is concerned with indicating the students' errors without actually correcting them. In other words, it involves indicating an error that the student makes without giving them the correct form. This can be done in a number of ways such as underlining the errors and using cursors to show omissions in the students' text. It can also be 'by placing a cross in the margin next to line containing the error' (Ellis, 2009). Several studies provide mixed results on the effectiveness of indirect corrective feedback. For example, Ellis (2009) reports that a study conducted by Lalande (1982) indicates that indirect corrective feedback enables learners to engage in reflective thinking about linguistic forms, which may likely to lead to long-term learning (Ferris and Roberts, 2001). However, this same study indicates that there are no significant differences between direct and indirect corrective feedback. In contrast, a study conducted by (Lee, 1997), cited by Ellis (2009), shows that learners improve their language efficiency if offered indirect feedback, but they prefer errors to be indicated and located, rather than errors that are just indicated by a cross in the margin.

\section{c. Metalinguistic corrective feedback}

As noted above, we will discuss only three types of feedback, and we now go on to discuss metalinguistic corrective feedback. This refers to a type of correction that is concerned with explicit comments about the nature of the errors that students make (Ellis, 2009). Ellis argues that this takes on two 
forms. Firstly, the use of error codes, which consists of an abbreviation label of the type of errors that learners make. He states further that this type of abbreviation label 'can be placed over the location of the error in the text or in the margin'. Secondly, the teacher should provide students with metalinguistic explanations of their errors. Ellis states that this type of metalinguistic feedback:-

...is far less common, perhaps because it is much more time consuming than using error codes and also because it calls for the teacher to possess sufficient metalinguistic knowledge to be able to write clear and accurate explanations for a variety of errors (p: 101).

This clearly shows that much time is needed, and the teacher has to possess adequate metalinguistic knowledge in order to enable them to provide appropriate written feedback to their students. Ellis (2009) claims that this type of metalinguistic feedback proves to be more effective than direct feedback in the long term. Having discussed a few different types of feedback, we will now review some previous studies conducted on written corrective feedback.

\section{Studies on written corrective feedback}

In the above section, various types of written corrective feedback have been discussed, including the three types limited for this study. Also noted above are the fact that there are debates of whether written corrective feedback would improve language performance or not. We now review some of the studies conducted on written corrective feedback.

Sheen (2007) conducted a study on the effect of focused written corrective feedback and language aptitude on ELS learners' acquisition of articles, on 111 intermediate-level students from across three language groups - Korean, Hispanic, and Polish. Sheen formed three groups of participants - a direct-only correction group, a direct metalinguistic correction group, and a control group. The result shows that both treatment groups performed better than the control group. Sheen concludes that written corrective feedback, focussing on a particular linguistic feature, improves learners' language accuracy, particularly if 'metalinguistic feedback was provided and the learners had high language analytic ability'. In a related study, Van Beuningen et al. (2012) investigated the effect of direct and indirect comprehensive written feedback on second language leaners' written accuracy. This study was conducted in four Dutch secondary schools, which have a multilingual student population, with 80 per cent of the students being from a non-Dutch language background. The result of this study shows that both direct and indirect comprehensive corrective feedback improved the language accuracy of the learners. Ferris (2006) also conducted a study on 
the impact of error feedback to student writers. This study was conducted at the California State University, Sacramento, with 92 ESL participants, 80 per cent of whom were immigrants. The results indicate that students provide effective revisions based on their teachers' response error marking. Lalande (1982) also conducted a study on six German students at Pennsylvania State University, on student written feedback, using two groups: control and treatment groups. The results show that the treatment group demonstrated a significant improvement with fewer errors in their revised work than the control group. It also shows that the combination of problem-solving techniques and raising awareness of errors had a significant beneficial effect on the development of writing skills.

In contrast, some studies show that there is a lack of improvement of students writing after they have received feedback. For example, Truscott (1996, 2007) argues that written corrective feedback does not improve language accuracy of the students on the premise that 'substantial research shows it to be ineffective... it has a harmful effect'. For Truscott, written corrective feedback is ineffective and is harmful for the students. A study conducted by Sheppard (1992) indicates that students who were not exposed to written corrective feedback performed much better in their writing tasks than those students who were exposed to written corrective feedback. In a similar study conducted by Polio and Fleck (1998), it was concluded that there is a lack of any improvement of language accuracy in the experimental group who received additional feedback, than the control group who did not receive any additional editing and feedback.

However, despite much varied research on written corrective feedback on students writing, the studies are mostly concerned with second language learners, particularly ESL, and with a few studies in other languages as a second language, notably Dutch, German, French, and so forth. There is a lack of substantial study on the native speakers' of other languages written corrective feedback, particularly in the Kuwaiti context. This study, as mentioned above, seeks to investigate the effect of indirect written corrective feedback of native Arabic speakers studying Arabic in the Kuwaiti context. We have noted above this study seeks to address two questions:

3. What kinds of errors recur in Arabic intermediate students' essay writing?

4. What kinds of feedback do Kuwaiti Arabic intermediate students require in their essay writing?

The methodology section of this study now follows. 


\section{The Study}

\section{Participants}

The participants of this study consist of both male and female students from five Arabic intermediate schools in Kuwait, studying on an Arabic course at intermediate level, during the second semester of the 2015/2016 academic session. We also conducted interviews with four informants in the schools. The research sample consists of 20 participants, 10 of each gender, all of whom are native speakers of Arabic. Writing composition is part of their curriculum, and every week students engage in writing tasks aimed at developing their writing and language skills. This study focuses on a written text corpus of 20 participants' two texts, of approximately 250 words per text, and with an approximate corpus of 10,000 words of the whole texts.

\section{Operationalisations}

As noted above, there are numerous types of feedback. In this study, we use indirect written corrective feedback, with errors identified in the students' essays highlighted, denoting that some errors occurred without the correct forms being provided. The rationale is to ascertain whether the native speakers of Arabic in this context of the study could improve their writing and language skills by offering them indirect feedback. In this study, we concentrate on the following errors: grammatical, spelling, morphological and organisational errors.

\section{Procedure and tasks}

As mentioned above, the study consists of 20 students from five Arabic intermediate schools in the state of Kuwait. There were two tasks, and each commenced with the discussion on raising awareness of the participants on the significance of writing a good essay, as well as avoiding many errors in the writing task. The first task assigned was for the students to write an essay. The following instructions were stated in the assigned task 1:

- You will have one hour to write an essay. You are requested to read the instructions and information carefully, which will help you to develop your essay.

Task 1

Write an essay of about 250 words, in Arabic, on how you spent your last holiday.

You should consider the criteria which determine the score of the essay. The criteria are the presence or absence of a clear point, paragraphing, overall organisation, grammar, and style of the essay. 
After they had written the essays, they were handed in to be marked. Some of the errors were highlighted, but the correct forms were not given.

After one week, a second task was conducted on the same topic. Before the task, a session was held with the students about the results of their first task. The second task was then distributed, which was the same with the first task.

The rationale was to ascertain whether the students had identified some of their errors in the first task, which they could then correct them in the second task. We followed the same instructions of task one and asked them to rewrite the essay as follows:

Task 2

Write an essay of about 250 words, in Arabic, on how you spent your last holiday.

The students wrote the essays and then handed them in. We marked the second essays which showed a greater improvement on their first essays. We will now present the results and discussion of the study.

\section{Results and discussion}

As noted above, the rationale for this study is to investigate whether intermediate native speaker students from five schools in Kuwait could improve their writing and language accuracy by offering them indirect written corrective feedback. Table 1 below shows the number and percentage of errors that the participants made in the first task.

Table 1: Number and percentage of errors in Task 1

\begin{tabular}{|l|l|l|}
\hline Types of error & Number of error & Percentage \\
\hline Grammatical errors & 82 & $28 \%$ \\
\hline Spelling errors & 162 & $56 \%$ \\
\hline Organisational errors & 46 & $16 \%$ \\
\hline Total & $\mathbf{2 9 0}$ & $\mathbf{1 0 0} \%$ \\
\hline
\end{tabular}

As can be seen in the above table (Table 1), the results show that the students in the first task conducted a number of errors. For example, there are 82 instances of grammatical errors, which accounted for $28 \%$ of the total errors in the corpus. Spelling errors have higher frequencies in the corpus, with 162 occurrences, which represents 56\% of the total errors in the corpus. In terms of organisational errors, there are 46 occurrences in their essays, which indicates that this type of error is the least among the three categories of errors being investigated in this study, with $16 \%$ of the total errors in the corpus. Having presented the results of the first task, students were not given feedback. In task two, as discussed above, some of the errors made in the first task were highlighted, but the students were not given the correct forms. We now present the results of the second task. 
Table 2: Number and percentage of errors in Task 2

\begin{tabular}{|l|l|l|}
\hline Types of error & Number of error & Percentage \\
\hline Grammatical errors & 10 & $10 \%$ \\
\hline Spelling errors & 84 & $86 \%$ \\
\hline Organisational errors & 4 & $4 \%$ \\
\hline Total & $\mathbf{9 8}$ & $\mathbf{1 0 0 \%}$ \\
\hline
\end{tabular}

As can be seen from the above table, Table 2, the results of the second task indicate that the number of errors reduced when compared with the results of the first task in Table 1 above. For example, grammatical errors reduced from 82 to 10, spelling errors from 162 to 84, and organisational errors from 46 to 4 . However, in order to test whether there is a strong statistical difference between the two results, we conducted a chi square test of association. The result of the statistical test is 28.2723 , and the p-value is $<0.00001$. This implies that the result is significant at $\mathrm{p}<.05$, suggesting that there is a significant statistical difference between the results of the first and second task. The overall results indicate that the students have made spelling errors more frequently than other errors, because in the first task it has a higher frequency among the three categories, as well as in the second task. Therefore, the students' performance towards correcting their errors without giving them direct written corrective feedback is effective.

This result is consistent with the findings of Lalande, which indicates that indirect corrective feedback enables learners to engage in reflective thinking about linguistic forms. It may also lead to long-term learning as argued by (Ferris and Roberts, 2001). It is also in contrast with the arguments of some scholars who believe that written corrective feedback is ineffective and does not improve the writing performance of students (Truscott, 2007, Polio and Fleck, 1998). As a result of this, the participants of this study could be given indirect written corrective feedback in their writing, as the above results of this study suggested. One remarkable feature is the higher reduction of grammatical and organisational errors in the second task. It could be possible that the higher reduction of grammatical errors might be associated with the fact that they are native speakers of the language, and therefore they could easily spot some of the errors being made in the first task. We now turn our discussion to some of the teaching implications.

Regarding the qualitative data suggests that the students could improve their correction if teachers could highlight errors without given them the correct form or answer on the premise that they know the correct forms but they tend to forget it in some instances. Having highlighted the errors, certainly would make them to remember the correct form and effect the change as one of the informants says: 
I know the correct form but sometimes I used to forget it. So if the errors were indicated I could easily identify them and make the correction (Student 1).

Perhaps it could be possible that this informant's narrative is as a result of the fact that he/she is a native speaker of Arabic language, which could easily spot the errors. Thus, he/she does not need direct written corrective feedback. However, some errors are beyond the notion of 'native speaker' on the premise that the errors might be associated with the structure of the argument, regardless whether a writer is native or non-native speaker. As such it depends upon the ability of the writer to positioning his/herself to the conventions of the said genre.

Furthermore, the contextual data also indicates that the informants are of the view that offering indirect written corrective feedback enables them to engage in critical thinking because the correct form has not been given to them. Following this, the writers are engaging in critical thinking in order to find and use the appropriate form. One of the informants says:

If I was not given the correct answer it enables me to engage in thinking of what appropriate should I use in this instance. Sometimes I used to spend quite long time thinking of the appropriate words but it enables me to develop deep thinking (student 3)

Certainly, this could help them to develop a critical thinking and the target language form would probably become automatization in them. It is also in line with the argument of Lalande (1982) which indicates that indirect corrective feedback enables learners to engage in reflective thinking about linguistic forms, which may likely to lead to long-term learning (Ferris and Roberts, 2001).

Moreover, one of the informants stresses that the indirect feedback provides the student with certain degree of autonomy in that the teacher does not impose his/her own authority to the students. In other words, students are allowed to think and choose appropriate form to be used unlike in direct written feedback students were given the correct form he/she must accept it. This corroborates Hyland and Hyland (2006) argument that giving direct feedback to students is a kind of imposing the students to accept teachers' point of views and does not encourage students' critical thinking to some extent. They argue further that teachers should strike a balance between giving direct and direct feedback.

However, one informant is of the opinion that indirect written feedback is not helping him because he usually gets confuse on the appropriate form to be used. As such he prefers direct feedback because he is 
more confident of himself if he was offered direct feedback. He narrates further:

In most cases I am very confused of indirect written feedback, I prefer direct feedback. Arm sometimes if you were given indirect feedback and corrected it might be possible the teacher would reject it if it is different from his own point of views (student 4).

It could be possible in some instances the students could be confused when offered indirect feedback, as such teachers should strike a balance when and what kind of feedback should I offer to the students.

\section{Teaching implications}

The results of this study, as noted above, indicate that native speakers of Arabic language studied in this research benefitted from indirect written corrective feedback. One of the teaching implications for language teachers is that native speakers of Arabic at intermediate schools in Kuwait could develop their writing and language skills by giving them indirect written corrective feedback. As such teachers should focus their attention on teaching and learning tasks which could concentrate on indirect written feedback rather than direct feedback. Again, as the above results have shown, the leaners have much more difficulty with spelling errors than any other errors, and therefore teachers should devise strategies which would concentrate on improving their spelling errors, such as writing the correct words. Since the results indicate that instructors' indirect corrections are effective, instructors should avoid offering the students direct corrections. They should avoid appropriation of students' texts (Hyland and Hyland, 2006). Again, teachers should not mark all the errors that students have made because it might discourage them from developing their writing and language skills. As such, only errors which instructors deem necessary to correct should be highlighted or drawn their students’ attention.

\section{Conclusion}

This study investigates whether indirect written corrective feedback could improve the writing and language performance of intermediate native speakers of Arabic students, as well as which errors recur in their writing. As the results have shown above, this improves their performance significantly by reducing the errors. Learners in this context can be offered indirect written corrective feedback. However, this study has some limitations: firstly, the study is not on a large scale involving a huge number of participants, and as such the study cannot make general conclusions on Kuwaiti intermediate native speakers of Arabic. As such, further research 
could increase the size and number of the participants in order to gain wider coverage in the Kuwaiti context.

\section{References:}

1. Baker, W. \& Bricker, R. H. (2010). The effects of direct and indirect speech acts on native English and ESL speakers' perception of teacher written feedback. System, 38, 75-84.

2. Beuningen, C. V., Jong, N. D. \& Kuiken, F. (2008). The effect of direct and indirect corrective feedback on L2 learners' written accuracy. ITL-Review of Applied Linguistics, 156, 279-296.

3. Bitchener, J. \& Knoch, U. (2009). The relative effectiveness of different types of direct written corrective feedback. System, 37, 322329.

4. Bruton, A. (2009). Designing research into the effects of grammar correction in L2 writing: Not so straightforward. Journal of Second Language Writing, 18, 136-140.

5. Chandler, J. (2003). The efficacy of various kinds of error feedback for improvement in the accuracy and fluency of L2 student writing. Journal of second language writing, 12, 267-296.

6. Conrad, S. M. \& Goldstein, L. M. (1999). ESL student revision after teacher-written comments: Text, contexts, and individuals. Journal of second language writing, 8, 147-179.

7. Doughty, C. J. \& Long, M. H. (2008). The handbook of second language acquisition, John Wiley \& Sons.

8. Ellis, R. (2009). A typology of written corrective feedback types. ELT journal, 63, 97-107.

9. Erel, S. \& Bulut, D. (2007). Error treatment in L2 writing: A comparative study of direct and indirect coded feedback in Turkish EFL context. Sosyal Bilimler Enstitüsü Dergisi Sayı, 22, 397-415.

10. Fathman, A. \& Whalley, E. (1990). Teacher response to student writing: Focus on form versus content. Second language writing: Research insights for the classroom, 9, 178-190.

11. Ferris, D. (2011). Treatment of error in second language student writing, University of Michigan Press.

12. Ferris, D. \& Roberts, B. (2001). Error feedback in L2 writing classes: How explicit does it need to be? Journal of second language writing, 10, 161-184.

13. Ferris, D. R. (1995). Student reactions to teacher response in multiple-draft composition classrooms. TESOL quarterly, 29, 33-53.

14. Ferris, D. R. (1997). The influence of teacher commentary on student revision. Tesol Quarterly, 31, 315-339. 
15. Ferris, D. R. (2006). Does error feedback help student writers? New evidence on the short-and long-term effects of written error correction. Feedback in second language writing: Contexts and issues, 81104.

16. Han, Z. (2002). A study of the impact of recasts on tense consistency in L2 output. TESOL quarterly, 543-572.

17. Hartshorn, K. J., Evans, N. W., Merrill, P. F., Sudweeks, R. R., Strong-krause, D. \& Anderson, N. J. (2010). Effects of dynamic corrective feedback on ESL writing accuracy. Tesol Quarterly, 44, 84-109.

18. Hashemnezhad, H. \& Mohammadnejad, S. (2012). A case for direct and indirect feedback: The other side of coin. English Language Teaching, 5, 230.

19. Hyland, K. \& Hyland, F. (2006). Feedback on second language students' writing. Language teaching, 39, 83-101.

20. Kao, C.-W. (2013). Effects of Focused Feedback on the Acquisition of Two English Articles. TESL-EJ, 17, n1.

21. Kepner, C. G. (1991). An experiment in the relationship of types of written feedback to the development of second-language writing skills. The modern language journal, 75, 305-313.

22. Lalande, J. F. (1982). Reducing composition errors: An experiment. The Modern Language Journal, 66, 140-149.

23. Lee, I. (1997). ESL learners' performance in error correction in writing: Some implications for teaching. System, 25, 465-477.

24. Lee, L. (2011). Focus-on-form through peer feedback in a SpanishAmerican telecollaborative exchange. Language Awareness, 20, 343357.

25. Long, M. H. (1996). The role of the linguistic environment in second language acquisition. Handbook of second language acquisition, 2, 413-468.

26. Lyster, R. (2004). Differential effects of prompts and recasts in formfocused instruction. Studies in second language acquisition, 26, 399432.

27. Mirzaii, M. \& Aliabadi, R. B. (2013). Direct and indirect written corrective feedback in the context of genre-based instruction on job application letter writing. Journal of Writing Research, 5, 191-213.

28. Montgomery, J. L. \& Baker, W. (2007). Teacher-written feedback: Student perceptions, teacher self-assessment, and actual teacher performance. Journal of Second Language Writing, 16, 82-99.

29. Polio, C. \& Fleck, C. (1998). “If I only had more time:” ESL learners' changes in linguistic accuracy on essay revisions. Journal of Second Language Writing, 7, 43-68. 
30. Santos, M., Serrano, S. L. \& Manchón, R. M. (2010). The differential effect of two types of direct written corrective feedback on noticing and uptake: Reformulation vs. error correction. International Journal of English Studies, 10, 131-154.

31. Sheen, Y. (2007). The effect of focused written corrective feedback and language aptitude on ESL learners' acquisition of articles. Tesol Quarterly, 41, 255-283.

32. Sheen, Y., Wright, D. \& Moldawa, A. (2009). Differential effects of focused and unfocused written correction on the accurate use of grammatical forms by adult ESL learners. System, 37, 556-569.

33. Sheppard, K. (1992). Two feedback types: Do they make a difference? RELC journal, 23, 103-110.

34. Truscott, J. (1996). The case against grammar correction in L2 writing classes. Language learning, 46, 327-369.

35. Truscott, J. (2007). The effect of error correction on learners' ability to write accurately. Journal of second language Writing, 16, 255-272.

36. Van Beuningen, C. (2010). Corrective feedback in L2 writing: Theoretical perspectives, empirical insights, and future directions. International Journal of English Studies, 10, 1-27.

37. Van Beuningen, C. G., De Jong, N. H. \& Kuiken, F. (2012). Evidence on the effectiveness of comprehensive error correction in second language writing. Language Learning, 62, 1-41.

38. Wigglesworth, G. \& Storch, N. (2012). What role for collaboration in writing and writing feedback. Journal of Second Language Writing, 21, 364-374.

39. Yilmaz, Y. (2012). The relative effects of explicit correction and recasts on two target structures via two communication modes. Language Learning, 62, 1134-1169. 